\title{
Estimation of Stature from Finger Length
}

\author{
Pooja Ahuja*2, Prajakta Manve ${ }^{1}$, Gloria Christal ${ }^{1}$ and MS Dahiya ${ }^{3}$ \\ ${ }^{1}$ Student, MSc. Forensic science, Institute of Forensic Science, Gujarat Forensic Sciences University, India \\ ${ }^{2}$ Assistant professor, Institute of Forensic Science, Gujarat Forensic Sciences University, India \\ ${ }^{3}$ Director, Institute of Forensic Science, Gujarat Forensic Sciences University, India
}

Submission: January 16, 2018; Published: January 24, 2018

*Corresponding author: Pooja Ahuja, Assistant professor, Institute of Forensic Science, Gujarat Forensic Sciences University, India, Email: pahuja159@gmail.com

\begin{abstract}
Identification of height of an individual in cases of commingled mutilated bodies has always been a concern for forensic cases. To determine stature in such cases, a database is required were in the estimation of stature from various body parts can be unearth. The present research was taken over people as a set of primary data. For the study the stature of individual and the length of the fingers were taken. Statistically significant correlation was observed between stature and finger lengths of left and right hand. The undertaken study clearly defines the multiplication factors for determining the stature from finger lengths. It can be opined that the stature of a living person can be determined from the finger lengths with high level of accuracy in cases of adolescent population.
\end{abstract}

Keywords: Stature; Finger length; Identification; Forensic

\section{Introduction}

Identification of an individual has always been a matter of concern especially in forensic cases like mass disasters, mutilated, commingled or says dismembered body parts found in murders, accidents and natural disasters. Identification can be done by various methods and techniques one of which is by estimating the stature. Anthropology deals with the study of human societies, cultures and their development. Physical Anthropology, also a part of anthropology is concerned with the study of the biological and physiological characteristics of human and their development. Factors like eating habits (nutritional factor), ethnicity and race also play vital role in growth and development of an individual. When a complete dead body is found stature the estimation of stature is easy, but in cases where only few body parts are available the estimation of stature is relatively a difficult task. Estimating the stature is based on the principle that every body part has a constant relationship with the height of a person. Various studies are done for estimating the stature of an individual by correlating the foot length, palm length and even ring and index finger with the height of a person. Very less data is available on correlating the height with the length of all fingers. Therefore, this study aims to cover this lacuna. The current study aims to estimate the stature from finger length. Two main terms that have to be understood here are stature and finger length. Stature or say height of an individual is the vertical distance from top of head to the bottom of feet, standing erect and Finger length is measured from the midpoint of bottom of the finger to the tip of the finger.

\section{Review of Literature}

Estimation of stature is very important in forensic anthropology and can be very helpful in the cases where mutilated bodies are found. The current study aims to identify the stature from finger length and to find the most reliable finger for the estimation of stature. One such study conducted by Suseelamma D et al. [1] was the Correlation between stature and length of fingers in which the objective of the study was to estimate stature from finger lengths and to predict the accuracy of regression models derived from such parameters [1]. The study was carried out 200 subjects of age group 18-60 years. It was found that there was significant difference $(P<0.001)$ between stature of male and female subjects and significant difference $(\mathrm{P}<0.001)$ between male and female finger length. Pearson correlation between finger length and stature was higher among males as compared to females. A second study was conducted by GM Raju et al. [2] on Estimation of stature from index and ring finger length in Davangere district. The study was conducted by taking the measurement of index and ring finger length of right hand and height of 250 medical students of age group 18 to 25 years. Statistical analysis was done to establish the relationship between a person's index and ring finger length of right hand and stature. Regression equation and ' $\mathrm{P}$ ' values were obtained. A moderate correlation was observed between the index and ring finger length of the right hand. Lastly Rajesh 
Vaijnathrao Bardale et al. [3] conducted a study on Estimation of stature from index and ring finger length3.The purpose of this study was to estimation of stature using index and ring finger lengths and to predict the accuracy of regression models derived from such parameters. The study was carried out on 195 students (100males and 95 females). There was significant difference (P $<0.001$ ) between stature of male and female subjects. Similarly significant difference $(\mathrm{P}<0.001)$ exists between male and female index and ring finger length. Correlation between finger length and stature was highly significant. Pearson correlation between finger length and stature was higher among females than males. The findings of present study indicate that index finger and ring finger lengths can be used to predict living stature of an individual $[4,5]$.

\section{Methods and Methodology}

The present study was carried over the students of Gujarat Forensic Sciences University, Gandhinagar, which is located in the western region of India. The study was carried out on a cross sectional sample of 200 adult students out of which 100 were males and 100 were females of 18-25 age groups [6-9]. The subjects are required to be above the age of 18 and below the age of 25. A general population of subjects were chosen for the purpose of the research. Data on sex, age and height were taken and the anthropometric measurements were taken in Figures 1 $\& 2$. For the measurement of height the subjects were made to stand in an upright position and with the help of a wall mounted tape the height was noted. Subjects were to be barefooted during the measurement of height. For the measurement of finger length the subjects were made to sit comfortably in an upright position and with the help of a Vernier caliper the finger length was measured. Subjects with missing fingers or extra fingers were not considered as subjects. The measurements were taken in centimetres. The data was analysed using the SPSS software (version 24) and Microsoft excel (2013).
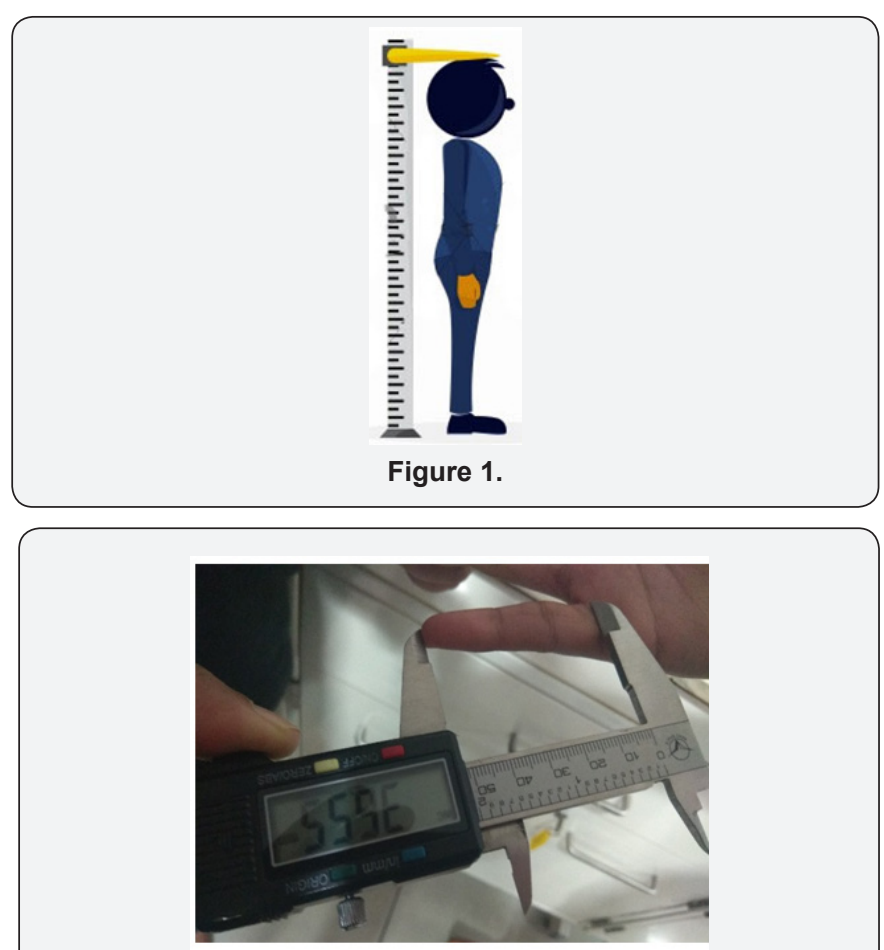

Figure 2.

\section{Results and Discussion}

The data collected from 100 males and 100 females were statistically analysed using the SPSS software. The correlation between the stature and the finger lengths was done along with the regression equation. The correlation was done using the SPSS software and the correlation coefficient was obtained as mentioned below and a positive correlation for both males and females was obtained for the estimation of the stature from finger length as mentioned in Tables $1 \& 2$.

Table 1: Correlation coefficient of females.

\begin{tabular}{|c|c|c|c|c|}
\hline S.no & Finger & Correlation Coefficient & Left Hand & Correlation Coefficient \\
\hline 1 & Right Thumb & .274 & Left Thumb & .266 \\
\hline 2 & Right Index & .573 & Left Index & .662 \\
\hline 3 & Right Middle & .692 & Left Middle & .665 \\
\hline 4 & Right Ring & .566 & Left Ring & .582 \\
\hline 5 & Right Little & .380 & Left Little & .540 \\
\hline
\end{tabular}

Table 2: Correlation coefficient of males.

\begin{tabular}{|c|c|c|c|c|}
\hline S.no & Finger & Correlation coefficient & Left hand & Correlation coefficient \\
\hline 1 & Right Thumb & .443 & Left Thumb & .456 \\
\hline 2 & Right Index & .553 & Left Index & .375 \\
\hline 3 & Right Middle & .666 & Left Middle & .528 \\
\hline 4 & Right Ring & .577 & Left Ring & .563 \\
\hline 5 & Right Little & .574 & Left Little & .437 \\
\hline
\end{tabular}




\section{Journal of Forensic Sciences \& Criminal Investigation}

According to the Linear Regression equation a statistically significant relationship was obtained between the stature and finger length. The formula was used to calculate the stature where,

$$
y=B 0+B 1 x
$$

Y= Height

Table 3: Table showing the values of $x$ for both males and females

\begin{tabular}{|c|c|c|}
\hline Finger & Female (X-Value) & Males X-Value) \\
\hline Right Thumb & 5.6 & 6.4 \\
\hline Right Index & 6.6 & 7.3 \\
\hline Right Middle & 7.2 & 7.0 \\
\hline Right Ring & 6.6 & 6.0 \\
\hline Right Little & 5.4 & 6.5 \\
\hline Left Thumb & 5.7 & 7.3 \\
\hline Left Index & 6.6 & 8.0 \\
\hline Left Middle & 7.2 & 7.4 \\
\hline Left Ring & 6.6 & 6.1 \\
\hline Left Little & 5.4 & \\
\hline
\end{tabular}

Table 4: Table showing the values of $\mathrm{B} 0$ and $\mathrm{B} 1$ for females.

\begin{tabular}{|c|c|c|}
\hline Finger & Constant (B0) & Regression Coefficient(In Cm) (B1) \\
\hline Right Thumb & 135.58 & 3.97 \\
\hline Right Index & 100.73 & 10.86 \\
\hline Right Middle & 79.00 & 8.51 \\
\hline Right Ring & 101.35 & 6.08 \\
\hline Right Little & 124.77 & 4.26 \\
\hline Left Thumb & 133.54 & 10.33 \\
\hline Left Index & 89.54 & 10.21 \\
\hline Left Middle & 83.35 & 8.81 \\
\hline Left Ring & 99.19 & 7.83 \\
\hline Left Little & 115.46 & \multicolumn{2}{|c|}{} \\
\hline
\end{tabular}

Table 5: Table showing the values of $\mathrm{B} 0$ and $\mathrm{B} 1$ for males.

\begin{tabular}{|c|c|c|}
\hline Finger & Constant (B0) & Regression Coefficient(in cm) (B1) \\
\hline Right Thumb & 140.94 & 5.02 \\
\hline Right Index & 133.02 & 9.23 \\
\hline Right Middle & 99.84 & 8.11 \\
\hline Right Ring & 111.96 & 9.43 \\
\hline Right Little & 116.21 & 5.87 \\
\hline Left Thumb & 134.98 & 2.89 \\
\hline Left Index & 152.07 & \multicolumn{2}{|c|}{6.34} \\
\hline Left Middle & 122.02 & 7.84 \\
\hline Left Ring & 114.72 & \multicolumn{2}{|c|}{} \\
\hline Left Little & 137.36 & \multicolumn{2}{|c|}{} \\
\hline
\end{tabular}

In forensic scenario with respect to the scenes of mass destructions the availability of the whole body for the purpose of examination cannot always be anticipated. In such scenarios the identification of the individual is questionable. With this current study if the fingers or the hand of the individual is available then
$\mathrm{B} 0=$ Constant $($ in $\mathrm{cm})$

B1 = Regression Coefficient $($ in $\mathrm{cm})$

$\mathrm{X}=$ finger length

The values of $\mathrm{X}, \mathrm{B} 0$ and $\mathrm{B} 1 \mathrm{are}$ mentioned in the following tables marked as Tables 3-5. 
Middle finger was found to be more reliable for the estimation of stature and it was also found that the Right index finger was the least reliable for the estimation of stature.

\section{Conclusion}

From the measurements taken from both the males and females it can be observed that males have more finger length and height. With respect to the above mentioned criteria the calculations were done accordingly. It can be concluded from this study that with the help of the Linear regression equation the successful estimation of stature can be done. The regression equation is a follows (as mentioned earlier):

$$
y=B 0+B 1 x
$$

Among the ten fingers of both the left and the right hand, the Left Index and Left Middle Finger were found to be more reliable for the estimation of stature. The study can be further continued by conducting over a larger population and can be done with respect to specific regions. One of the limitations of the study is that it cannot be generalized as the samples were collected from a small population.

\section{References}

1. Suseelamma D, Gayathri P, Deepthi S, Chandra Mohan M, Uday Kumar et al. (2014) Study of Correlation between Stature and Length of Fingers. Sch J App Med Sci 2(2D): 773-784.

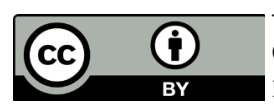

This work is licensed under Creative Commons Attribution 4.0 License

DOI : 10.19080/JFSCI.2018.07.555709
2. GM Raju, Shahina, Sarvesh Dubey, V Vijayanath (2014) Estimation of stature from index and ring finger length in Davangere district. International Journal of Clinical Trials 1(1): 18-21.

3. Rajesh VaijnathraoBardale, Taikhoom Mohammed Dahodwala, Vaibhav Digambar Sonar (2013) Estimation of Stature from Index and Ring Finger Length. J Indian Acad Forensic Med 35(4): 353-357.

4. Manoj Balachandran (2017) Estimation of Stature from the Length of the Right Index Finger in a Population in an Area in Dakshina Kannada and Sexual Dimorphism Exhibited. J Forensic Sci \& Criminal Inves 5(1): $1-8$.

5. Rastogi P, Kanchan T, Menezes RG, Yoganarasimha (2009) Middle finger length- a predictor of stature in the Indian population. Med Sci Law 49(2): 123-126.

6. Krishan K, Kanchan T, Asha N (2012) Estimation of stature from index finger length in north Indian adolescents population. J Forensic Med 19(5): 285-290.

7. Athawale MC (1963) Anthropological study of height from length of forearm bones. A study of one hundred Maharashtrian male adults of ages between twenty five and thirty years. Am J Phys Anthropol 21: 105-112.

8. Bhatnagar DP, Thapar SP Batish MK (1984) Identification of personal height from the somatometry of the hand in Punjabi males. Forensic Sci Int 24(2): 137-41.

9. http://www.heightdb.com/sites/default/files/best-time-daymeasure-height.jpg

\section{Your next submission with Juniper Publishers} will reach you the below assets

- Quality Editorial service

- Swift Peer Review

- Reprints availability

- E-prints Service

- Manuscript Podcast for convenient understanding

- Global attainment for your research

- Manuscript accessibility in different formats

( Pdf, E-pub, Full Text, Audio)

- Unceasing customer service

Track the below URL for one-step submission https://juniperpublishers.com/online-submission.php 